\title{
In Search of a Symbol Adequate to the Predicament: Seamus Heaney's Adaptation of Dante's “Ugolino" as a Redress of Poetry
}

\author{
Susan Poursanati \\ Allameh Tabataba'i University, Tehran, Iran
}

Copyright (c) 2019 by Susan Poursanati. This text may be archived and redistributed both in electronic form and in hard copy, provided that the author and journal are properly cited and no fee is charged for access.

\begin{abstract}
Seamus Heaney has introduced the theory of redress of poetry as a personal means to elaborate his poetic abilities and to respond to the conflicts in his native land, Northern Ireland. This theory bears some resemblances to the postcolonial and postmodernist theory of adaptation put forth by Linda Hutcheon. This paper aims at representing the similarities of Heaney's redress and Hutcheon's adaptation by exploring the functioning of these ideas in Heaney's translation of Dante's story of Ugolino. The main subjects addressed in this study are the definition of these two terms in the mentality of Heaney and Hutcheon; the institutional mechanisms involved in Heaney's adaptation of Dante's narrative; adaptation as a tripartite process of indigenisation; the significance of "Ugolino" in comparison with Heaney's earlier adaptations; the relation of this poem to the historical moment in which it is translated and the weaknesses and the strength of this technique.
\end{abstract}

Key Words. Irish poetry, Seamus Heaney, Dante, Adaptation, Redress of Poetry.

Resumen. Seamus Heaney avanzó la teoría de la reformulación de la poesía a modo de técnica personal para la elaboración de sus habilidades poéticas, así como respuesta a los conflictos de su país de origen, Irlanda del Norte. Dicha teoría destaca por sus similitudes con el concepto de adaptación, siguiendo un enfoque poscolonial y postmodernista, introducido por Linda Hutcheon. Este artículo tiene como objetivo señalar las conexiones entre las teorías de reformulación y adaptación de Heaney y Hutcheon, respectivamente, a través de un análisis de la puesta en práctica de dichas ideas en la traducción hecha por Heaney de la historia de Ugolino de Dante. Los principales aspectos que se observan en este estudio son la definición de ambos términos desde los puntos de vista de Heaney y Hutcheon, los mecanismos institucionales puestos en marcha en la adaptación de la narrativa de Dante realizada por Heaney, el concepto de adaptación como un proceso de indigenización tripartito, la importancia de "Ugolino" en contraste con otras adaptaciones anteriores de Heaney, la relación del poema traducido con el contexto histórico de su producción, y las ventajas y desventajas de esta técnica. 
Palabras clave. Poesía irlandesa, Seamus Heaney, Dante, adaptación, compensación de la poesía.

All poets experience the conflict between art and life and their character takes shape under the direct influence of these two powerful forces. The poets know that by oversimplifying the conflict or by opting for one of the poles, it would not resolve. However, they constantly wish to find an allegiance for such a complication. To clarify the conditions of the poets who feel the tension between art and life, Heaney re-names these forces as "song" and "suffering". When the poets find a refuge in "song", inadvertently and unintentionally, they betray "suffering". He deems the poets who prefer "song" in face of the utter suffering which afflicts people as irresponsible as the archetypal figure of Nero who played music while Rome was burning. Moreover, the poets' choice of "song" over life shows their affront to reality, while they enjoy the complacency of art (Heaney, The Government xi-xii). Irish poets have always felt this tension between the force of suffering and the complacency of artistic poetry. Michael Longley, the contemporary Irish poet, has complained of what is unfairly expected from them. On the one hand, if they write about the current violence in their society, a group of critics will accuse them of abusing the artistic purposes for the sake of political causes, and on the other, if they do not image the violence in their art, another group of critics will consider them guilty of artistic indifference (Ormsby xvii). In the violent conditions of Northern Ireland in the 1960s and 1970s Irish poets, including Seamus Heaney, were trapped in the duality between "I" and "Ireland" (Muldoon 35). A group of Heaney's critics has attempted to find out and scrutinise the creative ways through which this poet resolves the conflict between art and life, the poetics and the politics, or the "I" of the poet and "Ireland". For a deeper understanding of the mechanisms Heaney utilised to deal with the conflict of "song" and "suffering", the remarks of Eugene O'Brien, Sarah Fulford, Ashby Bland Crowder, and Jason David Hall are briefly introduced.

Eugene O'Brien's seminal book, Seamus Heaney Searches for the Answers (2003), examines the body of Heaney's poetry from 1966 to 2001 from the viewpoint of Derridean deconstruction. The relationship between binary oppositions and power structures; the transformative processes in poetic representations; the influence of the poetics on the politics, and the structures of place and language constitute major topics of O'Brien's study. In this book, O'Brien argues that "The creation of a complex and self-aware 'I' which is conscious of its constituent givens but which is also conscious of its agency, has been crucial element in his [Heaney's] aesthetic" (Answers 48). As an example of this special kind of poetic aesthetics, O'Brien refers to "Digging", the first poem in Heaney's first volume, Death of a Naturalist. For Heaney, in "Digging", poetry is not a mere tool to report real experiences; rather, it is a creative force which has the power of forming contexts for those experiences (37): "Between my finger and my thumb/ The squat pen rests. / I'll dig with it" (Lines 29-31, 2). In these lines, the methods through which the poet attempts to resolve the conflict between poetics and politics include rejecting the discursive teleology and creating subjectivity through language (O'Brien, Answers 34). In addition to language, the tension between time and place play a crucial role in Heaney's poetry (62). To represent Heaney's practice on the dialectics of time and place, O'Brien refers to the bog poems and place-name-poems in Heaney's earlier collections. As he discusses, Irish place names are historically and ideologically dense and capable of associating the person with his/her political identity and attitude (113). For instance, Heaney represents the bond between an Irish place and time in the poem "Anahorish", in Wintering Out: 
My 'place of clear water',

the first hill in the world

where springs washed into

the shiny grass (Lines $1-4,6)$

In a similar but more collective way, in Heaney's series of bog poems, he reads the ground of Ireland as a metaphor of a "Jungian psychic memory" as is represented in the opening parts of the volumes Wintering Out and North (O'Brien, "Telling the Truth Slant" 281). The poem "The Tollund Man" in Wintering Out is an example:

Out there in Jutland

In the old man-killing parishes

I will feel lost,

Unhappy and at home. (Part III, lines 9-12)

To sum up, O'Brien has addressed experimenting with language, time, and place as the most important poetic answers given by the poet to the political conflict in Northern Ireland.

The formation of the Irish national identity and Irish poets' flight from traditional nationalism are the building blocks of Sarah Fulford's book Gendered Spaces in Contemporary Irish Poetry (2002). In her argument, Fulford introduces the terms "postcolonial nationalism" and "postcolonial-post nationalism". She suggests that the poet has experienced and perceived this duality as an individual and moves from the former to the latter to resolve his artistic conflicts. She implies that due to the experience of colonisation, the people of Ireland feel uprooted from their land; thus, they are in search of a solid ground upon which they can construct their communal identity. Nationalism and processes of excluding what is not Irish are the outcomes of this type of mentality (Fulford 30-31). However, she believes that Heaney's poetry's potential goes beyond the nationalist exclusionism and involves postcolonial-post nationalism in poems such as "Ocean's Love to Ireland", in the collection North, in which the Irish narrator is given voice and tries to come into terms with the history of colonisation and the basic agency of a non-Irish existence, England, by telling the story of Ireland's colonisation through the allegory of raping a maid by a man.

A collection of essays edited by Ashby Bland Crowder and Jason David Hall, Seamus Heaney: Poet, Critic, Translator (2007) deals with international and general aspects of Heaney's poems, his works of prose and translations, and their reception. Here, the essays written by Stephen Regan and Barbara Hardy are briefly reviewed. Regan, in "Seamus Heaney and the Modern Elegy", argues that in search of the emblems of adversity, Heaney has found a parallel between the sectarian murder in his contemporary Northern Ireland and the ritual sacrifices in all areas of Northern Europe during the Iron Age (in Crowder and Hall 14). This narrative technique, Regan asserts, is the unique historiographic way through which the poet merges the mythic and the contemporary socio-historical realities. He refers to the poem "Funeral Rites" as an example which juxtaposes the dead of the past mythological contexts with those murdered in the present violence. In her essay, "Literary Allusions, Apparitions and Assimilations", Hardy states that intertextuality is the joint force of Heaney's creativity in and counts the reasons which motivated Heaney to make his literary intertexts: first, intertextuality and collage were fashionable during Heaney's poetic career; second, he wanted to change the traditional way of writing lyrical narratives, and third, he has been a student, instructor, and critic of literature (in Crowder and Hall 189). However, Hardy does not discuss the political overtones in Heaney's adaptations and prefers to treat them as the poet's artistic choice. 
In the abovementioned critical works, as the ideas are briefly overviewed, O'Brien tends to associate Heaney's resolution of the conflict between art and life with language, locality, and temporality; Fulford addresses the interplay between post-colonial nationalism and postcolonial-post nationalism as the main strategy of the poet in dealing with poetics and politics; Regan and Hardy, respectively, consider juxtaposition of myth and contemporary history, and intertextuality as Heaney's main techniques in aligning his "I" with "Ireland". However, none of these analyses and those similar to them refer to adaptation as an independent way of resolving the conflict between "song" and "suffering" and as a way Heaney chose to comment on his historical/political moment. Therefore, the present paper aims to introduce adaptation as one of Heaney's political and poetic resolutions.

In The Place of Writing, Heaney argues that the process of creating an artistic work "involves raising the historical record to a different power" (qtd. in Crowder and Hall 174). Hence, to imagine a better vision of the future, first, the poets should dig up the alternative versions of historical narratives of the pasts (Flannery 50). To do this, they would involve in artistic-reformulation of the past along their attempts in reflecting a realistic image of the present moment. Pursuing this mode in his volume of poetry, Field Work, published in 1979, Heaney, in search of a new focal point in his field of work, deals with contemporary political issues in Northern Ireland with a new perspective which addresses questions on the poet's responsibilities, his political commitment, and violence in the society (Bogen 8). He asserts that in Field Work he changes his voice to a more open public/social enunciation (in Randall 16). And as one of Heaney's critics has claimed it is noticeable that from Field Work onwards he adds self-commentary to the political/aesthetic and public/local binary oppositions in his works (O'Donoghue 5). This poetical mode of self-commentary, manifested in the form of adaptation, is the main subject of discussion in this paper exploiting Heaney's conception of the redress of poetry and Linda Hutcheon's formula of postmodernist adaptation.

Heaney has theorised his poetics in various lectures and works of prose. He used the expression redress of poetry in one of his lectures, later, published in a book with the same title in 1990. The redress of poetry, as Heaney defines it, can cover his practice of providing poetic-social commentary in the volume Field Work. However, this expression is the specific term defined and applied by a poet to his poetic practice. Therefore, while on the one hand the analysis of the expression redress of poetry may open the windows to the personal aspect of Heaney's theoretical approach, a more universal concept can help to shed light on how the poet interacted with the general artistic trends of his time, e.g. postmodernist and postcolonial theories, which stand as parallels to his personal ideas. Consequently, the argument attempts to match Hutcheon's term, postmodernist adaptation, and Heaney's term, redress of poetry, to present personal as well as universal aspects of Heaney's poetics and to reveal one of the mechanisms through which the poet provides his social commentary.

To pin the meaning of the term redress of poetry down, Heaney first makes a brief recourse to the formal and dictionary meaning of the word redress:

The OED has four entries for 'redress' as a noun, and I began by calling upon the first sense which it provides: 'Reparation of, satisfaction or compensation for, a wrong sustained or the loss resulting from this.' For 'redress' as a verb the dictionary usages noted as obsolete. I have also taken account of the first of these obsolete meanings, which is given as, 'To set (a person or a thing) upright again; to raise again to an erect position. Also fig. to set up again, restore, re-establish'... a further (obsolete) meaning of 'redress', with which I would conclude, a meaning which comes in entry four of the verb, subsection (b): 'Hunting. To bring back (the hounds or deer) to the proper course.' In this 'redress' there is no hint of ethical obligation; it is more a matter of finding a course for the breakaway of innate capacity, a course 
where something unhindered, yet directed, can sweep ahead into its full potential. (Redress 20-21)

Moreover, the writer, claims Heaney, starts as a reader who, even before initiating the act of writing, has internalised the "tradition" (Redress 15). The word tradition used by Heaney in this context can, possibly, imply a conceptual relation to what T.S. Eliot termed "tradition" in his essay "Tradition and the Individual Talent" as:

It involves; in the first place, the historical sense, which we may call nearly indispensable to anyone who would continue to be a poet beyond his twenty-fifth year; and the historical sense involves a perception, not only of the pastness of the past, but of its presence; the historical sense compels, a man to write not merely with his own generation in his bones, but with a feeling that the whole of the literature of Europe from Homer and within it the whole of the literature of his own country has a simultaneous existence and composes a simultaneous order. This historical sense which is a sense of the timeless as well as of the temporal and of the timeless and of the temporal together, is what makes a writer traditional. And it is at the same time what makes a writer most acutely conscious of his place in time, of his own contemporaneity. (Eliot 1093)

Heaney further develops the idea of historical sense in poetry by expressing the viewpoint that: "Poetry, let us say, whether it belongs to an old political dispensation or aspires to express a new one, has to be a working model of inclusive consciousness. It should not simplify. Its projections and inventions should be a match for the complex reality which surrounds it and out of which it is generated" (Redress 16). He continues to justify the validity of Dante's The Divine Comedy as a work which perfectly fits into this formula of poetry (Redress 16) and follows his theoretical ideas in composing poems.

From the practical point of view, the redress of poetry motivates the poet, first, to present something new which the "audience will recognize as something old" and second, to simultaneously stand inside and outside of the socio-historical context (Heaney, Redress 143). From the realistic point of view, Heaney does not consider the discrepancy between what is real and what is imaginary contradictory because he observes that "if our given experience is a labyrinth, then its impassability is countered by the poet's imagining some equivalent of the labyrinth and bringing himself and the reader through it" (141). Heaney explains that the redress of poetry is "a sensation both of arrival and of prospect, so that one does indeed seem to 'recover a past' and 'prefigure a future', and thereby to complete the circle of one's being" (17). The redress of poetry, finally, is a kind of answer given in the language of poetry and not in the language of the world. This language-based distinction is a poetic answer that determines the task of poetry and imagination when they face the harsh realities and the pressure of the world (141) in general and of Heaney's Ireland, in particular.

The redress of poetry is an endeavour to find an answer for a lifelong conflict in the mind of the poet that whether poets should feel social responsibilities or put their art superior to social events. To elucidate the term redress, he claims that to "effect the redress of poetry, it is not necessary for the poet to be aiming deliberately at social or political change" (Redress 141) and that the idea of the redress might be a third alternative to resolve the conflict in the mind of the poet. The redress of poetry, therefore, is kind of and/both condition which "need[s] to be both socially responsible and creatively free" (142). Regardless of whether a convincing argument and artistic resolution for Heaney's critics who had accused him of perpetuating violence via his art in the collection North (Johnston qtd. in Campbell 114), the idea of the redress of poetry is seemingly a working and agreeable idea for Heaney who had 
tested it in Field Work long before theorising it in the book, A Redress of Poetry.

Mapping out Heaney's idea of the redress, now the argument can shift to Hutcheon. In her book, A Theory of Adaptation (2006), Hutcheon explores adaptation as a postmodernist historiographical device. When a work of art is an adaptation, it means that it detaches itself from the time, the space, and the locality of the original work. Adaptation, moreover, is a rich device for postcolonial artists who wish to re-narrate their own nations via exploiting the texts of the colonisers. The adapted works can attract the audience as they mix familiarity with novelty. However, Hutcheon notes that adapting other works may also involve elitist processes due to the reasons discussed later in this paper.

Adaptation is a repetition combined with variation. It gives the audience the pleasure of simultaneous remembrance and change. While the theme and the narrative structure persist, the material and the method of narration may vary and thus, adaptations are not just simple reproductions (Hutcheon 4); they are:

- An acknowledged transposition of a recognizable other work or works

- A creative and an interpretive act of appropriation/salvaging

- An extended intertextual engagement with the adapted work

Therefore, an adaptation is a derivation that is not derivative - a work that is second without being secondary. It is its own palimpsestic thing (8-9).

The experience of reading such a text includes first, knowing that it is an adaptation, and then letting it merge with what one has already kept in the memory so that the mind can fill the gaps of the new text with what it remembers from the earlier text (120-21). In this way, postcolonial artists have used adaptations to articulate a particular political position with a sense of historical intentionality and political agency (94). It is noteworthy that such texts may retain the historical accuracy, but they wilfully re-interpret the adapted works for a totally new and different context (153). Being familiar with the conditions of postcoloniality, Heaney is a possible example of Hutcheon's adaptation.

Heaney suggests that the "truly creative writer, by interposing his or her perception and expression will transfigure the conditions and effect thereby what I have called the redress of poetry" (Redress 118). He considers the process of writing others' poetry into his poetry or what postmodernist critics like Hutcheon call adaptation as the redress of poetry: "when poets turn to the great masters of the past, they turn to an image of their own creation, one which is likely to be a reflection of their own imaginative needs, their own artistic inclinations and procedures" ("Dante" 5). Adaptation, thus, makes up the procedures of transforming of an attitude in a new context which can represent the authors' acceptance or resistance towards it (Said 226-7). In this sense, both Heaney's redress and Hutcheon's adaptation involve finding recourse to the past works of literature to re-interpret and to transplant them into a new socio-historical context with the aim of contributing to the understanding of the readers via activating their cultural/communal memory. To check the redress and adaptation in practice, Heaney's translation of one part of Dante's The Divine Comedy, "Ugolino", is analysed and the following observations are made:

First, in the adapted works the travel of the stories through time and place results in bringing together different representational and institutional processes. According to Edward Said, the stories, ideas or theories which travel through time, place, or their representational format, involve four elements: "a set of initial circumstances, a distance traversed, a set of conditions of acceptance (or resistance), and a transformation of the idea in its new time and place" (226-27). In addition to these four elements, it is noteworthy that the local particularities of stories that the authors transplant into the new grounds of the host culture are hybrid and new. Said's first element "a set of initial circumstances" exists in Heaney's poetical worldview. In his lecture in Royal Society of Literature in 1974, "Feeling into Words" he asserts that the Belfast of the summer of 1969 has been a turning point in his 
career as a poet (qtd. in Terence Brown 192) and in his book Preoccupations he states that "The problems of poetry moved from simply being a matter of achieving a satisfactory verbal icon to being a search for images and symbols adequate to our predicament" (Heaney 56). Thus, the poet can offer his solution and show his responsibility as a social figure by introducing "befitting emblems of adversity" into his poetry (57). The Belfast of 1969 forms the "initial circumstance" for Heaney's search for the fitting and adequate symbols of the Irish Troubles ${ }^{1}$ in the literature of the past. Obviously, the second element emphasised by Said, "a distance traversed", matches Heaney's "Ugolino" as it does not share the temporal, geographical, cultural, and linguistic context of Dante's poem. As mentioned before, the most immediate receivers of Heaney's poems, the people of Northern Ireland, suffered from the Irish Troubles and thus they were ready to either accept or decline resolutions provided by poetry; hence, Said's third element, "a set of conditions for acceptance (or resistance)": (If your sympathy has not already started/ At all that my heart was foresuffering/ And if you are not crying, you are hardhearted) (Opened Ground, Lines 56-58, 188). Finally, Heaney's "Ugolino" meets Said's last criteria, "a transformation of the idea in its new time and place", as the poem is a translation which Heaney's readers might interpret differently through their horizon of expectations.

The second general observation related to the analysis of redress and adaptation in Heaney's "Ugolino" addresses the views of some other critics, who similar to Said, have discussed travelling of stories through time and space; for instance, Susan Stanford Friedman, Hutcheon explains, has used

[A]nthropological term "indigenization" to refer to this kind of intercultural encounter and accommodation (2004). In political discourse, indigenization is used within a national setting to refer to the forming of a national discourse different from the dominant; in a religious context, as in mission church discourse, it refers to a nativized church and a recontextualized Christianity. But the advantage of the more general anthropological usage in thinking about adaptation is that it implies agency: people pick and choose what they want to transplant to their own soil. Adapters of traveling stories exert power over what they adapt. (150)

Not only is Heaney's translation an example of what Friedman has termed "indigenization" in its political sense as he re-installs the narrative belonging to one nation in the narrative of another nation, but also interestingly, it is, possibly, a thoughtful religious "indigenization" because Heaney as a Catholic changes the religious context of the story from one reflecting a Catholic society to one which addresses the Northern Irish society in which most of the population are Protestants and in strife with the Catholics. However, Hutcheon's final sentence implying the anthropological function of the adaptation that the "Adapters of traveling stories exert power over what they adapt" is more important than what Friedman has brought forth. In this sense, Heaney is justifiably the master of Dante's text and by translating it, he can turn it into the narrative of his own nation and its two conflicting groups. Thus, the reference of the pronoun "I" in the following lines is, possibly, Heaney and not Dante:

So the berserk Tydeus gnashed and fed Upon the severed head of Menalippus As if it were some spattered carnal melon.

'You,' I shouted, 'you on top, what hate

Makes you so ravenous and insatiable?

What keeps you so monstrously at rut?

Is there any story I can tell 
For you, in the world above, against him? (Opened Ground, lines 7-14, 187)

Third, as an important strategy in postmodern historiography, adaptation often figures in Heaney's poetry. Heaney had adapted the literature of the English colonisers into the context of his own poetry earlier in his career. The poem "Bog Oak", published in the volume Wintering Out, for instance, ends not with the poet's personal remarks but with adapting an extract from Edmund Spenser's A View on the Present State of Ireland as an intertext. What is significant about this specific intertext is that Heaney has ironically adapted a text written by the coloniser about the colonised subject into the narrative of the colonised:

Perhaps I just make out
Edmund Spenser,
dreaming sunlight,
encroached upon by
geniuses who creep
'out of every corner
of the woodes and glennes'
towards watercress and carrion. (Lines 21-28, 4-5)

In addition to Spenser, the sequence "A Northern Hoard", in the same volume, begins with an epigraph from Samuel Taylor Coleridge's "The Rime of the Ancient Mariner": "And some in dreams assured were/ Of the spirit that plagued us so" (29). Taking the two lines out of their original context - the context of the literature of the coloniser - the poet adapts them to the discourse of colonisation to represent his resistance. The word "some" may refer to the people of Ireland who are in dreams, and in their dreams, they have undeniable knowledge about the colonisers and Ireland, and the "Spirit" may signify English imperialism that brought about chaos and mayhem to the Irish people. This poem can embody the idea of postcolonial adaptation put forward by Hutcheon by transplanting a part of the literature of the coloniser into the literature of the colonised as a marker of postcolonial resistance (94). This approach towards the literature of other nations turns into new forms in Heaney's poetry as he found out that Dante's Comedia is an apt choice for his adaptations. From Filed Work onwards, he explicitly revealed his relationship with Dante (Guite 210) and in an interview, he said that he felt Dante could add a cosmopolitan angle to the contemporary condition of Catholicism in Ireland (qtd. in Bloom 71). His translation of "Ugolino" is an adaptation as he has attempted to match the main idea which the poem presents about Dante's native land with the contemporary struggles over possessing Ireland. In this poem, the opponents are versioned so closely linked together that one of them constantly eats the contents of the other's skull. The poet offers Ugolino to narrate his story so that he can place an embargo on his opponent in the upper levels (the Paradise): "If my tongue by then's not withered in my throat /I will report the truth and clear your name" (Opened Ground, lines 13-16, 187). Unlike the poems of the volume North in which Heaney gives voice to Catholics and nationalists, in Field Work and "Ugolino" the poet sings for the troubles of all the residents of the island (Hildebidle in Bloom 77). The poem remarks that whosoever betrays his land deserves to suffer a punishment like Ugolino: to see his children dying in front of his eyes, "I stared in my sons' faces and spoke no word" (Line 64), and to eat the kernel of the skull of his opponent. The poem is significant as the two enemies in it easily identify with a Republican and a Loyalist, and Ulster is, possibly the "nightmare tower", pictured in the poem, wherein the sins of the fathers inflict upon innocent children (Parker in Bloom 79). In the story of Ugolino's betrayal to his country, a series of consecutive murders happen in which many innocent people die, and violence perpetuates. Heaney, by re-writing the story of Ugolino, comments on the 
violence and ongoing murders in Ireland where one murder leads to another (74). In other words, he warns the people of Ireland that if they do not stop the murders, the violence will continue, their sufferings will intensify in the future (Curtis in Bloom 75), and they will live in a place which may resemble Dante's Inferno.

Fourth, knowing Heaney's definition of the redress, the reader cannot ignore the historical moment in which "Ugolino" is published. The poem is first published as part of the volume Field Work in 1979. This volume succeeds the poet's previous volume, North, which Helen Vendler has called "one of the most crucial poetic interventions of the twentieth century" (qtd. in Cobb 110). If North is Heaney's direct and heated response to the trauma of the Irish Troubles, Field Work is his post-traumatic response almost about ten years after the days of rebellion and anguish. Exploring how to cope with the pressure of reality, Heaney finds Wallace Stevens's statement a working formula. Stevens suggests that poetry "is a violence from within that protects us from a violence without" to deal with reality (qtd. in Redress 12). To follow this formula in order to deal with the conditions of his country, he counts Dante's The Divine Comedy as an old work which both belongs to the past and relates to the modern context as what Dante has imagined in that work corresponds to what Heaney's contemporaries conceive (Redress 16). Further, he claims that "Whatever is given', I wrote in one of my own poems, 'Can always be reimagined, however foursquare, / Plank-thick, hull-stupid and out of its time / It happens to be"' (qtd. in Redress 147):

Still, you should know my name, for I was Count

Ugolino, this was Archbishop Roger,

And why I act the jockey to his mount

Is surely common knowledge; how my good faith

Was easy prey to his malignancy,

How I was taken, held, and put to death.

But you must hear something you cannot know

If you're to judge him - the cruelty

Of my death at his hands. So listen now. (Opened Ground, lines 29-37, 188)

Heaney's version of "Ugolino", therefore, is a possible re-imagination of an old story to transfer the violence in the streets of Northern Ireland to the realms of the literary tradition and the poetic narratives.

Fifth, Heaney's use of adaptation in "Ugolino" can be significant in two ways, one socially positive and the other negative. The positive point is that through the medium of adaptation he has found a way to comment on social issues and even to warn his nation about the outcomes of ongoing violence. The negative point is that the use of adaptation and narrating an old story in a second context opens up a gap between the real event in the new context and the adapted story. As Hutcheon notes, adaptation can turn into an elitist phenomenon which gives the artist a kind aesthetic pleasure (117), instead of conveying his/her message to the readers. In other words, this adaptation can confuse those readers who cannot detect the artistic codes linking the two narratives of Dante's Ugolino and his enemy, on the one hand, and Heaney's Protestant and Catholic, on the other:

And saw two soldered in a frozen hole

On top of other, one's skull capping the other's,

Gnawing at him where the neck and head

Are grafted to the sweet fruit of the brain,

Like a famine victim at a loaf of bread. (Opened Ground, Lines 2-6, 187) 
Here Heaney's choice of words is very smart as the word famine in line six can bring to mind part of the Irish history, the Great Famine. ${ }^{2}$ However, such dexterous and subtle poetic choices might remain unrecognisable to his readers in Ireland. Moreover, De Quesnay has complained that the form appeals to the aesthetics of the intellectuals because the act of understanding the interplay of the texts is an easier task for them than for other readers (Hutcheon 117). As a result, while this method of the redressing of poetry might have positive effects on the Irish nation, it surely adds new complications to their problems as even if they understand Heaney's national implications, they inevitably should identify with a people living in a context far away from them both culturally and historically. In other words, the conflict between Ugolino and his enemy in the Middle Ages is not exactly the equivalent of the conflict between the Northern Irish Catholic and Protestant groups.

In conclusion, in Field Work, the poet's artistic response to the troubled social scene is three-dimensional. First, he more explicitly reveals his affiliation with his own social group; second, he uncovers and articulates his poetic doubts, ambiguities, and ambivalences, and third, he re-considers the question of the real/worldly powers of poetry to find an answer to the questions already explored in Wintering Out and North. Furthermore, not only is Heaney synchronised with the artistic trends of his own day usages but also he contributes his personal attitude and poetics to those trends trough introducing notions like the redress of poetry. Finally, Heaney's attempt in "Ugolino" manifests his social concerns in addition to his artistic ones. However elitist and vague his answer and his representation of the Irish Troubles might seem to the readers, what is significant is that when his nation was in trouble and conflict, he strived to avoid being an island entire of himself.

\section{Notes}

\footnotetext{
${ }^{1}$ The Troubles is the name given to the sectarian conflict which flared up in Northern Ireland in 1968 when the civil rights movement provoked a backlash which resulted in paramilitary violence and attacks upon the police and British troops (who were sent into the province in 1969). The peace process has seen a reduction but not a complete end to political violence (Plowright 300).

${ }^{2}$ The famine (1847-51), following a blight (1845), ruined the potato crop which was the staple diet of the population. About one million died of starvation and disease and two more millions emigrated during and after the famine. The failure or unwillingness of the government to provide adequate relief greatly intensified antiEnglish tendencies (Collins Dictionary of British History 242).
}

\section{Works Cited}

Bloom, Harold. Seamus Heaney. Broomall: Chelsea House, 2003.

Bogen, Don. "Heaney's Touch". Rev. of The Spirit Level, by Seamus Heaney. The Three Penny Review 68 (1997): 8-9.

Brown, Terence. Literature of Ireland Culture and Criticism. Cambridge: Cambridge UP, 2010.

Campbell, Matthew, ed. The Cambridge Companion to Contemporary Irish Poetry. New York: Cambridge UP, 2003.

Cobb, Ann. "Opened Ground: Poems 1966-1996 by Seamus Heaney". Rev. of Seamus Heaney, by Helen Vendler. Harvard Review 16 (1999): 108-110.

Collins Dictionary of British History. New York: Harper Collins, 2002. 
Crowder, Ashby B., and Jason David Hall, eds. Seamus Heaney Poet Critic Translator. New York: Palgrave MacMillan, 2007.

Eliot, Thomas S. "The Tradition and the Individual Talent". The Norton Anthology of Theory and Criticism. New York: Norton, 2001. 1088-1091.

Flannery, Eoin. Ireland and Postcolonial Studies: Theory, Discourse, Utopia. New York: Palgrave McMillan, 2009.

Fulford, Sarah. Gendered Spaces in Contemporary Irish Poetry. Bern: Peter Lang, 2002.

Guite, Malcolm. "The Replenishing Fountain: Hope and Renewal in the Poetry of Seamus Heaney". Faith, Hope, and Poetry: Theology and the Poetic Imagination. Surrey: Ashgate, 2012. 201-242.

Heaney, Seamus "Envies and Identifications: Dante and the Modern Poet". Irish University Review 15-1(1985): 5-19.

_. Opened Ground: Poems 1966-1996. London: Faber and Faber, 1998.

_. Preoccupations: Selected Prose 1968-1978. London: Faber and Faber, 1980.

- The Government of the Tongue. London: Faber and Faber, 1989.

. The Redress of Poetry. Macmillan, epub.

Wintering Out. London: Faber and Faber, 1972.

Hutcheon, Linda. A Theory of Adaptation. London: Routledge, 2006.

Muldoon, Paul. To Ireland, I. Oxford: Oxford UP, 2000.

O’Brien, Eugene. Seamus Heaney Searches for Answers. London: Pluto, 2003.

"Telling the Truth Slant". A Companion to Irish Literature. Vol. 2. Ed. Julia M. Wright. West Sussex: Wiley-Blackwell, 2010. 281-295.

O'Donoghue, Bernard, ed. The Cambridge Companion to Seamus Heaney. New York: Cambridge UP, 2009.

Ormsby, Frank. A Rage for Orders: Poetry of Northern Ireland Troubles. Belfast: Blackstaff, 1992.

Plowright, John: The Routledge Dictionary of Modern British History. London: Routledge, 2006.

Randall, James, and Seamus Heaney. "An Interview with Seamus Heaney”. Ploughshares 5-3 (1979): 7-22.

Said, Edward W. The World, the Text, and the Critic. Cambridge: Harvard UP, 1983.

Received: 25 April 2018 Revised version accepted: 1 September 2018

Susan Poursanati is a lecturer at the Department of English Language and Literature, Faculty of Persian Literature and Foreign Languages, Allameh Tabataba'i University, Tehran, Iran, and a visiting lecturer at The University of Tehran where she has taught undergraduate, graduate, and postgraduate literature courses (History of English Literature, Postcolonial Studies, Samples of Simple Poetry, Contemporary Poetry, and Romantic Poetry). She received her doctoral degree in English Language and Literature from the University of Tehran, Faculty of Foreign Languages and Literatures, 2015, with a study entitled Elitism and Colonial Critique: Seamus Heaney's Poetic Narrative of the Irish Past and Present. Her research interests include mainly the area of Irish studies, Postcolonial studies, Romantic poetry, and Modernist Poetry. Recently, she has become involved in the study of the poetry of female Irish and Scottish poets.

susan.poursanati@gmail.com 